\title{
聖者伝資料に見られるビザンツ社会の空間と聖性
}

\section{Space and the Holy in Byzantium according to Hagiographic Sources}

\author{
ミッシェル・カプラン \\ Michel L. G. KAPLAN \\ (大月康弘訳)
}

(本稿は, 日本ビザンツ学会と一橋大学地中海研究会の共催によって開催されたカプ ラン氏来日講演会の報告原稿邦訳である。詳細については末尾の【解説】を参照された い)

《凡例》聖者の生没年を Bibliotheca Hagiographica Graeca, I-II. ed, F, Halkin. Bruxelles, 1957. によって付記する。また，聖者伝諸版情報も BHG 番号をもって示す。 なお，傍点は，訳者の責任において必要に応じ付した。

ビザンツ社会における空間と聖性の関係は, これまでもつぱら美術史家と考古学者に よって研究されてきた。そこでは, 建築様式や装飾の観点からモニュメントの空間構成 が分析され，記述テクストが問題にされることはそれほどなかった。

エジプトのスケテへの修道士たちの入植について研究したベルナール・フリューザン の分析は， 5 世紀成立の『教父筬言集』と，同じ教父たちに関して $7 \sim 8$ 世紀に書かれ た聖者伝を比較するものだった。前者では，空間構成の場やその構成方法にほとんど関 心が払われていない。これに対し, 後者では, 聖所の恒久的存続が最重要な関心となっ ている。後者では, 聖遺物の巡回によって保証される当該場所の聖性が謳われながら, スケテが聖山に仕立て上げられるのである。フリューザンは, 「聖性が, 修道士から, 注ぎ込まれる場所へと移っている」と結論した。フリューザンは, こうして鿵修制 érémitique, 共住制 cénobitique の修道生活が各々どのように空間を考えたのか，その 種々の仕方を指摘してみせたのだった。この点にはのちに立ち戻りたい。

* パリ第一大学 ビザンティンおよび中世中東の歴史と文明研究センター教授, 同所長, パリ第一大学長

Professeur à l'Université Paris I/Directeur du Centre de Recherches d'Histoire et Civilisation byzantines et du Proche Orient médiéval de l'Université Paris I/ Président de l'Université Paris I

** 一橋大学大学院経済学研究科助教授

Associate Professor at Postgraduate School of Economics, Hitotsubashi University 
近年, 我々は (オーセルの中世研究所と共同して)「ビザンツと西欧における聖性とそ の空間構成」について 2 年にわたり検討してきた。この分析によって実に多くの主題が 大きく進展した。異教的な聖空間の聖別のされ方。聖なる空間がイコノクラスム期にお いて聖所だけに集中したそのあり方。聖なる空間が立ち上げられる当初期での聖空間の 選択のされ方。そして, 聖山概念。これらの論点に立ち入って紹介することは差し控え るが, 聖山については再び立ち戻ろう。

いくつか方法論の定義をしておこう。我々が扱う問題の各々にしばしば起こることが ある。まず，ただ 1 通の聖者伝のみしかなく，他に考古学的遺物が一切残されないとい う事態である。伝記が伝える聖空間の定義は, 聖者その人というより, 何よりも聖者伝 作者のものであり，両者には重要なずれがある。例えば,『小エウテュミオス伝』(898没， BHG 655)。テッサロニキ大主教（バシリオス）の執筆だが，作者は, 悔い改めることが なかった聖者の隱修生活を批判する。ほぼ同時代に書かれた諸版が伝承されるケースも ある。例えば 9 世紀の『ヨアニキオス伝』(846没)。聖者は何よりも鿵修士であり, 聖空 間に関する問いは二次的である。サバス版（BHG 935）とペトロス版（BHG 936）を付 き合わせても，何も引き出せない。あるいはまた，必ずしも同時代ではないが，異なる 人物によって発注され，聖空間についても全く異なる認識を示す複数の記述を持ち合わ せもする。もっとも顕著な例は，柱頭行者シメオン（459没, BHG 1678-1688) の場合で ある。この聖者伝は, ジャン=ピエール・ソッディーニ指導の考古学的成果と比較する ことができる。シメオン伝には現在 3 つの写本がある。最古の版は，キュロス府主教テ オドレトスによってシメオン存命中に書かれたが，これは聖空間についてはほとんど顧 慮しない。もちろんそれはシメオン没後に出来した聖所とは無縁である。第 2 の版は, シメオン没後まもなくシリア語で書かれ, 聖者の柱の周囲に集った会衆のために執筆さ れた——もっともこの聖遺物はアンティオキアに移送されていたが——第 3 の版は, アントニオスによってギリシャ語で書かれ，シリアの中心都市の風景を伝える。

ときに我々は，聖者伝に特化し幾人かの聖者の伝記を残した作者に出くわす。かかる 聖者伝は，作者の意困をアクチュアルに示すものだ。そのような作者としてもっとも有 名な例は，6世紀にスキトポリス大主教となったパレスティナのキュリロスである。彼 の作品は, 種々の考古学上の遺物と比較可能でもある。キュリロスが残したもっとも長 編の聖者伝作品『エウテュミオス伝』(473没, BHG 648) と『サバス伝』(532没, BHG 1608）は, 我々の関心にとってまさに興味深い比類のない二作品である。作者は一人なの に，聖なる空間認識が同一でない。それは，一定の仕方で，聖者たちの聖空間認識を反 映しているといってよい。

我々が扱った聖者伝の大部分は，葬儀を含めて聖者の死をもって終わる。なかには聖 
堂および聖所の建設にまで話が及ぶものもある。かかる建設担当者が聖者伝発注者とい うこともある。聖所にはときに聖遺物が移葬される。この出来事はテクスト構成に織り 込まれて，テクストを独特なものにする。『テッサロニキのテオドラ伝』(892没，BHG 1737-1741）の場合のように, 聖遺物の移葬が聖者伝の本体部分に密接に関連することも ある。しかし, 聖遺物の移葬は, 聖者の死とその最初の葬儀とからは明らかに距離があ る。我々は，かかる聖遺物の移葬に関わる記述をしばらく考慮に入れないこととしたい。 我々は，同じく奇跡譚も考察対象としない。奇跡譚には，聖空間が伝記作者の主要な 関心事であり，中心的特徵であり，巡礼対象である，という事実がある。しかし，これ は別途研究対象とするにふさわしい。奇跡譚の作者は, 長いこと明らかだった話題の中 心人物の聖性を明証する必要がなく, 聖者独自の聖空間認識を表明する必要もない。聖 者が聖なる空間をいかにして創り出したかについても, 聖者伝の場合ほど説明の必要が ないのである。実際, 奇跡を為す者は, 聖母のように聖書中の登場人物や, テクラのよ うに聖書の登場人物に近い人物，あるいはまた，定義上聖者である殉教者である。奇跡 譚の記述には, 空間の聖別と, 聖者の列聖とのあいだの相関が見られない。

主題を 2 つに分けてみよう。まず，独自に聖空間を創り出す聖者なる存在一般につい て検討しよう。それを，鿵修士も共住修道士も含めて修道士的聖者を中心に見ていこう。 主教だった聖者の伝記は, 此較的数が少ないのに加えて, 聖空間についてほとんど何も 提供しないからである。異教が未だ消滅しておらず，キリスト教の聖空間と異教の聖空 間との対立がいまだ顕著だった 6 世紀と，修道制が教会制度と社会全体の中によく根付 き, 聖空間の創出後は, 聖者の存在がもはやその修道院に限らず広範囲に広がった11世 紀とでは，目覚ましい進展の跡が認められる。6世紀から11世紀にかけてのこの進展が 聖空間にどう対応しているか。それは, 今後とも追究されるべき研究テーマだが, 聖空 間が広がったことから様々な変化があったことは明らかだ。しかし，その変化はおそら く聖性のモデル自体の変化に対応している。

空間に深く刻み込まれた聖性パターンのあるものは，6世紀間を通じて持続した。つ まり，柱頭聖者である。この類型は，大シメオンから一一その聖所は11世紀にあっても 使われていた——゙レシオンのラザロス（1053没, BHG 979-980）まで，恰好の事例群 が連なっている。隔絶された切立った山の脇に暮らす者もいれば,町中やコンスタンティ ノープル近くに暮らす者もいた。一連の事例を見ると，柱頭聖者たちの聖空間が，どの ようなかたちで展開したかを，一般的な空間パターンと比較することができる。

聖者が行う第一のステップは, 聖者が自身の目的を実現させる場所を選び，そこに住 


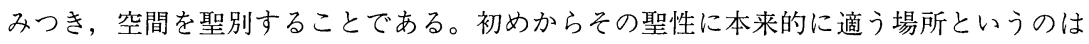
存在しない。聖者こそが, その場所に聖性を創り出すのである。たとえ鿵修士的生活が 聖者を人里離れた場所に向かわたとしても，事態は同じである。事態は，まるでかかる 聖空間がそれまで知られていなかったかの如くである。しかし，テクストをより綿密に 検討すると, 大半の聖空間が聖者に親しみある場所だったり, 聖者が住み着いた場所が 実はすでに聖化されていたりしていたことが判明する。いずれにせよその場所は，神も しくは神性を具えた者, 聖母や天使, 他の聖者などによって指し示されることとなるだ ろう。この問題をより詳しく検証してみると, 聖者が真に積極的な参加をしている場合 には，聖者伝中のこのトポスがさらに強い意味を帯びてくるはずである。聖者伝作者は，

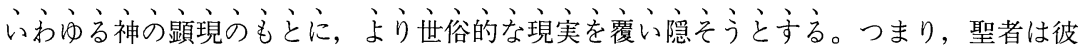
がしたいことを厳密に行うが, 彼は, そうすることで当地う教会機構と衝突している, ということである。この衝突は，立ち上げを目論む聖所を聖別する上で避けて通れない。 もちろん, 聖者が聖空間とほぼ同一視されてくると一一聖者伝作者がその最初の擁護者 であり，聖者伝が示す聖所がその最初の恩龍である——，一般に聖者伝は，その聖なる 場所の選択と顕示を，神の仲介に帰すことになる。しかしこれは，大半の聖者がその場 所を単に精神的基準で選択したわけでないことを，隠蔽しえているわけではない。要す るに，神の提案があっても人間が行為している，ということだ。

以下の例は, 神の選択がアンビヴァレントなことをよく示している。6世紀前半の柱 頭行者小シメオン (521生-592没, BHG 1689-1691) にとって,「崇高な山」mons Milabili 以外に神の顕現がある場所はあっただろうか。この若者は, 煩わしい追従者たちから逃 れるために住み着く場所を知らなかった。彼は, 庵を結んで人気のないのを確認した山 に，柱を建てることを思いついた。阌巡する間に，彼はキリストが山から降り立つのを 見た。キリストはこう言葉をかけた。「シメオンよ，急ぎたまえ。恐れず，崇高なる山に 登りなさい。その山は，私がそれを聖別したが故に以後その名によってそう呼ばれるの であって, この山の上で, 汝の名を崇高なるものとしょう。なぜなら, 私が汝とともに あるのだから」。キリストは小シメオンに登るべき岩山を示し, シメオンはのちにそこに 柱を立てるのであった。聖者伝は，この山が，聖者が切り開くことになる処女地だった， と我々に思わせたがっている。ところが現実は全く違う。新たに誕生した共同体のため に水の在処を見つける必要が生じたとき, 教会や修道院はまだ建設段階だった。「山の中 腹に, ヘレニズム時代に作られた 2 つのさな雨水を溜める水槽があった。人々は, 家 畜とともにやって来て，水の欠乏に苦しんで，かつてそれを造った。聖者はパイプを修 復するよう命じた。」柱頭行者小シメオンは, 山の上部に建っていた古代の聖堂に棲み着 いたのである。聖堂は, 長いこと宗教活動に参加して水を必要としてきた人々を引き寄 
せていたのだった（類似の話しはよくある）。

もっとも単純な手続きは，異教の聖空間をキリスト教のそれに転換させることだった。 パンフュリア地方出身のペルゲのマトゥロナ（5-6 世紀, BHG 1221-1223）がそうした ように,である。東方に向けて出発した彼女は, ベイルートを通り, 打ち捨てられた異 教神殿を, 詩篇を朗誦しながらキリスト教の聖堂に転用した。十字架の徵によって, 古 代の神殿の門に火を放った悪魔に対抗し，それらを退散させたのである。貴族身分の異 教徒の男たちは, 妻らが大挙してマトゥロナに合流したものだから，火をもって彼女を 威嚇したが，それは何よりも，異教の神殿が，神聖でキリス卜教的なものに転換したこ とを示している。しかしそこは，最終的にマトゥロナの鿵棲場所となる聖空間にはなら なかった。というのも，マトゥロナはある女性修道院の長としてコンスタンティノープ ルに戻ったからである。同様に柱頭行者アリピオス（BHG 64-66d）は，600年頃パフラ ゴニアにおいて，悪魔の悪戯で打ち捨てられていた墓地の所有権を手にした。彼は, 墓 の上にそびえる，ライオンの頭をした牛の像を頂く柱に目をつけた。彼は，その像を置 き換えるべく柱に登るが，その前に聖女ユウフェミアの廟 martyrion を建て，そこから 悪しき霊気を追い払った。古代の墓は，今や聖者の聖空間になるのを待つばかりであっ た。墓の周りに修道院が建てられる間, アリピオスは柱に登っていた。

聖なる空間を創り出すために悪魔を追い払うこと。それは,なにも異教空間だけに限っ たことではなく, ある種不可避な行為だった。他方, 悪魔の霊気から解放された自由空 間が, 常に異教的というわけでもなかった。例之ば, ユダヤの砂漠で, サバスは共住生 活用の施設に転用するために，カステリオン castellion を手に入れた。名前が示すよう に，そこにはかつてユダヤ人が居住した建物があり，悪魔に取り憑かれていたのだった。 サバスは聖油を撒いて悪魔を追い払う。するとそこは, 庵 kellia 結ぶための石材を切 り出すだけでなく，修道士らが既存の建物を再び利用できる空間になったのだった。石 材を切り出す途上で, サバスはヴォールトの架かった古い部屋を発見し，これを新施設 の教会堂に転用した。

キリスト教徒は，修道士でさえも，空間を放棄して悪魔に委ねることがあった。小工 ウテュミオスは，ブラスタノで隐修士として静かに暮らしていた。アトス半島が開かれ たとき，彼は，テッサロニキ近郊のペリステライに向かうよう幻視から告げられた。そ こで彼は，使徒アンドレアに献納された囲い地を見つけることになる。ところが，そこ は荒れ果て羊の囲い地に変えられていた。小エウテュミオスは，その地を自分のものと して確保したが，悪魔と戦わねばならなかった。悪魔は，聖者が再興を達成する間に， その世俗化の機会を㝝っていた。それは870/871年の出来事だった。この時代になると， もはや悪魔は異教のものではなく，キリスト教の聖空間の世俗化にまつわるものになっ 
ている。もっとも, 悪魔が聖者伝のなかで重要な役割を果なしているといっても, 聖空 間との関係においては，ますます稀薄な存在になっていることは，銘記しておこう。

逆に, 聖遺物の存在は, 聖者によって選ばれた空間の聖別にとって必須の条件になる。 この関心は，主に初期の聖者伝に見られる。例えば，ヒパティオス（446没， BHG 760) は, ルフィニアネ修道院の聖堂に収蔵される聖アンモニオス（3世紀の聖人）の遺物を 躊躇することなく所持した。聖アンモニオスの棺は，446年に修道士たちの手で同聖堂に 納められていた。534年からほどなくして書かれた『アコイメトスの聖マルケロス伝』

(469以降没, BHG 1027, 1028) では, イレネオンでの聖遺物の受容に長大な一章が割か れた。柱頭行者大シメオンの聖遺物を移葬することは, 柱頭行者ダニエル (493没)にとっ て，マンドラ mandra の聖性を完全にするための一大関心事だった。同様に，小シメオ ンの母マルタの伝記（551没, BHG 1174）によると, 小シメオンは, イェルサレムのス トラヴォヒュラクス stravophylax から本物の聖十字架の木片を入手し, 自身の母の聖 遺物の脇に置いたという。もう一度確認しておこう。この種の関心は時代とともに薄れ ていく。

聖者が確保しようとする空間の境界を確定することは, 必要事である。それは, 551年 6 月 4 日に「崇高な山」で起こった。この日は, 聖霊降臨祭の日曜日で, 小シメオンが, 山の頂上に最後にしつらえた柱の上に登ることになっていた。それは，すでにマンドラ の壁に囲まれていた聖なる空間を確定するための最後のステップだった。母マルタが十 字架を手にし, 修道院の周囲に共同体の成員全員を集めて行列の先頭に立った。彼女は 教会に戻り，シメオンを柱の上に乗せた。

一つの重要な発展が, 実に速いテンポで生じていた。 5 世紀, ガザ主教ポルピュリオ スは, 皇后エウドキキアからの書簡で, 自身のカテドラルのプランを受け取った。柱頭 行者小シメオンは, 幻視のなかで天使から修道院と教会の図面を受け取った。彼は, こ れを遂行すべく，従者たちにプランを手渡す必要があった。神より示されるプラン。こ のトポスはその後もしばしば見られる。例えば，10世紀のスパルタで，メタノイテスの ニコン (998没, BHG 1366-1368）が救世主キリストの聖堂を建てようとしていたが, 彼 は幻視によってそのプランを受け取った。彼は, 行列の先頭に立って, 聖堂から選ばれ た場所に行く。幻視は三次元的なものだった。2つの列柱を造らせ，建物の内部空間を 囲み，屋根を莫かせた。

聖堂以外で，修道士が関わるという意味では「囲い」が大変重要だった（もっともそ の重要性も次第に減じていくが)。マンドラの壁は, もともと柱頭行者を特徴付ける要素 だった。それは，柱を建てる以前に為される行為である。これについては後に見ること としよう。 9 世紀, ペルゲのマトゥロナは, その師バッシアノスの施設をまねて修道施 
設の建設に着手する前に，周囲を囲った。

スキトポリスのキュリロスが執筆した聖者伝は，伝記作者が「囲い」をどう考えてい たかを伝える格好の事例である。『エウテュミオス伝』では，ラヴラ（鿵修修道院）とコ イノビオン (共住修道院) とが対照的に描かれていて，ラヴラの空間はモノで囲われる 必要がない。かくして, 公現祭の 8 日目に, 人々は強い渇望からラヴラに詰め寄ること ができた。聖者は彼の小聖堂 kellion から出て, 群衆に会いに向かった。しかし，そこに は何の壁も門もなかった。その後まもなくして，皇后エウドキア (404没，アルカディウ ス帝の后）が，ラヴラから3.5キロメートル離れた対面の高台に聖ぺテロ教会を建て，水 槽の建設を見にやって来たとき，彼女は「眼前に，尊者エウテュミオスのラヴラが，砂 漠に撒かれたように点在するケリア（小庵）とともにあるのを見た」。つまり，ラヴラの 空間は開放的なのだった。

逆に，コイノビオン（共住修道院）の空間は閉ざされている。エウテュミオスは，最 終的に自分のラヴラがコイノビオンとなるようにした。これは，イェルサレム総大主教 の宗主権のもとで行われた。スキトポリス府主教だった伝記作者は, 教会機構から見た 修道院の空間編成について語っている。それは, エウテュミオスが遺言執行者フィドス に対し，コイノビオン建設のためにケリアを取り払うことを命じたことからも理解でき る。フィドスは実際に遺言を執行し, 修道院を壁で囲って要塞化した。こうして, 囲い, とりわけ門は，大きな役割を果たしていた。ある者は，奇跡にあやかるために囲いの中 に入ることを許され，聖者の墓の近くで瞑想を行い，あるいは聖者の墓の上でそうする ことができた。しかし他の者にはそれが許されなかった。例えば，ハギアズマ hagiasma を飲んだべタブディッサ村からやってくるある女性は, 毎年, 門に接吻をしにやってき た。ラヴラは今やコイノビオンになり，聖者伝作者によって標準的な修道院類型に仕立 て上げられた。サバスは自分のラヴラを見下ろす塔をもっていた。しかし，扉はなく， 門も壁もあったとは言及されない。ラヴラは，ヒエラルヒー化された階層秩序の中心性 を獲得していた(これについては後段で考察する)。ところが, 残りの施設群は, ワジ・ ケドロンの両脇に点在する小庵を含めて, 組織化されてはいない。

ところが，「囲い」は，次第に聖者伝作者のなかで副次的な関心事となっていく。例之 ば， 7 世紀前半の『シケオンのテオドロス伝』（613没，BHG 1748, 1749）は，聖者の建 てた建物についてはいずれも詳細に記すものの, 外部との遮断状況について何一つ述べ ていない。10世紀末，『ラトロス山のパウロス伝』(955没, BHG 1474）の作者は, パウ ロスのラヴラが鲶修士として暮らす数名の修道士から成る, と記している。数名の者は建 物と台所を共用していた。しかし, 伝記作者は, パウロスが座すアヒイロピエテ acheiropoiete と呼ばれる柱を取り囲む空間に見られたはずの「囲い」については，全く言及し 
ない。これは，アトスについても同じである。アタナシオス（1004没）が創設したアトス 最初の大規模修道院ラヴラでは，ケリア群がまさに「囲い」となっていた。ところが, 初期の『アタナシオス伝』（BHG 187）はその詳細を記していない。「一つひとつのケリ オンを結びつけようとする」聖者を描く『アタナシオス伝』は，数十年後に書かれた第 二のヴァージョン（BHG 188）を待たなければならない。2つの聖者伝の間に過ぎ去つ た時間を経てはじめて，この記述は必要なものとなった。しかしそれは，アタナシオス 自身や彼の最初の伝記作者にとっては不可欠なものではなかったのである。

隠者的生活と聖化された空間とには，一つの矛盾が介在する。小エウトュミオス (898 没）の伝記に立ち戻ろう。聖者伝作者バシリオスは，聖者の弟子からテッサロニキの大 主教になった。彼は隠者の賛同者であり，かつ教会秩序の厳格な擁護者であった。この ことは，聖性が，境を明確にする聖なる空間に登録されていたことを含意する。小エウ ティミオスは様々な活動を行った人だった。隠遁生活を好んだ彼は，しばしば荒野— アトスも当時まだ荒野だった——に駆り立てられ，その後ついには孤島で没する。とこ ろが, 彼はときに共住生活（コイノビオン）を受け入れる。ある幻視が，彼にぺリステ ライ所在の聖アンドレアス修道院を再建することを命じる。この幻視はこう述べた（こ れは明らかに聖者伝作者が語ることである)。「悪魔と戦うには，荒野で暮らすことでは 満足されまい」。修道院が再建されるやいなや, 彼は自身の柱を見つけるために直ちに テッサロニキ近郊に旅立つ。その後アトスに入り, そこで求めていた平穏を見いだすこ とになる。

『ラトロス山のパウロス伝』では, 聖者が住む狭い峡谷以外に, 聖なる空間とされる 場はない。ラヴラでの修道士たちの生活ぶりを記述する際にも, 空間の境が言及される ことはない。限定されない空間に暮らす者を，共同体に暮らす者と区別するだけである。 伝記作者は, 空間を神聖化するのに聖者の死を待つ。955年12月15日にパウロスは没し, 聖者の遺骸が回収されて聖なる空間が創られた。遺骸は, 神聖ではあるが境界のないラ ヴラ空間内の礼择堂に安置される。修道院長シメオンは, 聖者の遺骸を安置する墓所を 囲うため, 礼洋堂の建設を決定した。しかし, しかるべき場所と, 選ばれたラヴラの指 示は, 事前には全く出されない。2つの岩が人間の介入を阻んでいた。修道士たちが岩 の上に立っていると, 柱頭に聖者が現われ, 十字の徴が広がった。院長は, 選ばれた高 位聖職者とともにラヴラの岩に現われたこの十字を認証し, 伝記中その場所は特定でき ないものの，明らかに修道院近くであるこの聖なる空間を見定めた。岩はチーズのよう に事なく分断され, 礼洋堂の建設が可能となった。聖者の遺骸は, 命日ごとに修道院と は別の場所に移されることとなったのである。聖者は聖なる空間なしでも生きられる。 しかしそれは，聖者伝作者が創出しようとする聖性なしでは生きられない。 
聖者の周囲で限定される聖空間。それが一一少なくとも聖者の存命中に一一顕現して ないならないほど，聖者が用いる空間のシステムは，逆にますます広がっていった。『エ ウトュミオス伝』（473没，BHG 648）に立ち戻ろう。修道院の囲いによって限定されな い聖者の聖空間は，本当は「区域（テリトリー)」を限定している。例えば，あるよそ者 が聖者の遺骨を聖遺物箱から盗み出した。ところが，その者は翌日，扉の前の大地に釘 を打ち付けられて見つかった。この者は距離にして30マイルを歩いたが, “修道院の境界” と述べられるところを越えてはいなかったのである。つまり聖者は，その聖遺物を内陣 の外へ，共住施設の中心である礼捧堂の外へ，あるいはまた囲いの外にさえ持ち出させ たが，聖空間を規定するこの実体のない境界を越えさせはしなかったのである。これは， スキトポリスのキュリロスによって念入りに記述され，限定されたものだった。区域（テ リトリー）の観念は，『サバス伝』(532没，BHG 1608）において，より明瞭に見られる。 ラヴラないしサバスに従属する空間の支配は，伝記中の大きな関心事である。サバスは， 彼のラヴラの「場所」topoi を尊重することを注意深く命じる。それは，ラヴラのテリト リーがおよそ $3.5 \mathrm{~km}$ の範囲に収まる区域だったと見えるものである。例えば，修道士ヤ コブは, ケドロン渓谷にあった中心ラヴラから約 $2.6 \mathrm{~km}$ のころにあった「七つ口貯水 池」一一聖サバスが水を飲んだ場所——に，ラヴラを 1 つ建て始めた。このとき聖者は, 建物群を壊させ，区域（テリトリー）をはっきりさせるために，属院を中心ラヴラの北 方 $900 \mathrm{~m}$ の地に建設させた。後に, ザンノスのコイノビオン（共住修道院）が $2.6 \mathrm{~km}$ 南 の場所に建てられる。さらにサバスは, 洞窟コイノビオンにとって邪魔となっていた羊 飼いたちを「修道院の場から」外に出させた。洞窟コイノビオンもまた，こうして物理 的にも精神的にもこの区域（テリトリー）内にあった。

区域の拡大を示す好例は，『メタノイテスのニコン伝』(998没, BHG 1366) に得られ る。これは, 1042年頃に同修道院の院長によって書かれ，すでに「救世主と聖キリアケの 記念聖堂」の建設過程について見た作品である。病のニコンが, ナルテックスにその身 を横たえるよう頼むが, 聖者の死後に何が起こったのか。記述は矛盾する。街頭が群集 で満ちあふれたという。人々は聖堂の「境域」から離れまいとする。それは, 修道院を 囲む壁の存在を示すと言えるかもしれない。しかしここでは単純に, 聖堂外壁に群集が 群がったと理解したい。人々は聖堂の中に入り込もうとする。このとき，聖者の支配す る聖空間は聖堂だけであり，そこでは多くの奇蹟が起こっている。しかし，聖者伝作者 はますますもって「修道院」という言葉を用いる。中に居る人々も, あからさまに修道 士と呼ばれる。修道院の区画を実際に作り出したのは修道院長グレゴリオスだったが, 彼は，黄金印電付き皇帝文書と施設の所有権に関わる諸権限を手に入れるため，コンス タンティノープルに赴く。彼は, 皇帝からの贈り物とともに戻り，この施物をもって聖 
堂を柱廊で囲み，前庭と階段を造り，町なかにあった修道院を「囲い」を設けて仕切っ た。その後, 聖者は奇跡を起こすが, それは，修道院の外，あるいはまた町の外に一部 置き換えられる。つまり, 聖ニコンの礼洋堂がある属院 metochion に置き換えられるの である。礼洋堂は, 聖者の奇跡をもたらすイコンが納められたところから, ニコンの聖 なる空間の一部なのだった。

聖者伝作者が聖なる空間を規定するには, 様々な仕方がある。ひとたびこの空間が定 義されると, 聖者伝作者は, それが組織化されたものとして, とりわけ教会の位階制の

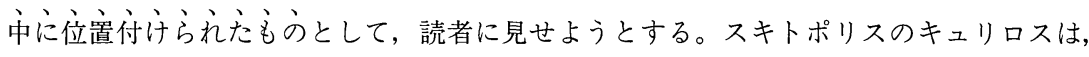
微妙に異なる二つの状況について記している。彼はおそらく, 主人公たちの考えの違い を記しているのである。『エウテュミオス伝』では, 聖なる空間は全く再構築される。つ まり，聖者の死後，施設は完全に再建され，ラヴラがコイノビオンになった。これは, イェルサレム総大主教の監督下でフィドスによって行われた。フィドスは，エウテュミ オスが当初棲み始めた洞窟を壊して墓所にした。中央に聖者の墓を置き，その周囲に歴 代修道院長の墓, そして司祭と修道士の墓を配した。大主教は, 聖者の墓を教会の内陣 で囲ませた。それから，自らエウテュミオスを横たえたその場所に，銀の聖遺物入れを もってこさせ，持参した銀の板を，聖者のちょうど胸の上に，聖者の心臓の上にかぶさ せた。つまり，中央には聖者が，その回りに聖遺物入れが，その回りに墓が，その回り に内陣が, その回りに共同体の他のメンバーが位階の順序に従って, さらにその回りに 礼洋堂が, 設定されたのである。こう処置してから, フィドスはコイノビオンを設立し た。「彼は，真ん中に葬祭用の礼拝堂をもつことに成功した」。コイノビオンは囲まれて おり，囲いの中には塔とともに小奄（ケリア）があり，古い教会堂が還俗されて食堂に 転用され，それよりも高い位置に新しい教会堂が造られたことも付言してよいだろう。

それらの施設に序列を付けるのは難しい。『サバス伝』では, 唯一の判断基準として, 聖者がかつて火柱を目撃した場所が挙げられている。そこは, 古くからの洞窟教会が建う ていた所で，サバスに啓示があった場所だった。サバスは，パン工房や病院，ラヴラの 人口に相応しい規模のテオトコス教会を新たに建てたが，その建設時に「2つの教会の 間に火柱の幻影が現われ, そこに庭がつくられた」。聖者の没後, 教会機構, とりわけイエ ルサレム大主教がラヴラを支配するに至って初めて，それは話題となった。自然の洞穴 か人の手による洞窟を用いたかたちで, 墓が建てられる。聖遺物が総主教ぺトロスの手 でそこに置かれ，他の修道士たちが埋葬されることになった。聖遺物は，そこに在るこ とで，中央の区画をラヴラの精神的拠り所へと転化させたのである。

空間の神聖化。それは，聖者その人というょり聖者伝作者にとって切実な問題である。 それは主うぱら聖者の没後に起こる。聖なる空間を著名にし，令名を維持すべく聖者伝 
作者が筆を執るとき，この問題は発生する。テッサロニキのテオドラ (892没) の例が示 すように，それはときに厳しい。テオドラは，施設の創設者でもなく，所属した聖ステ ファナ女子修道院の長でもなかった。聖空間が重要な関心事とはならなかった隐者や, 施設の設立者や再建者, あるいは何かの宗教施設の精神的指導者だった隀者は別として, 彼女の境遇は大多数の聖者とは違う。彼女は, 慎ましく修道生活を送り, 没し, 埋葬さ れた。テッサロニキ大主教と縁続きだったが，女子修道院長に推挙されることを拒んだ。 その晚年, 聖ステファナの院長は彼女自身の娘テオフィスタだった。

テオドラは固有の聖空間をもたなかった。没後にこれを付与されることも拒絶した。 娘でもあった修道院長テオフィス夕は, テオドラのために院内に特別な墓を設置するこ とを望んだ。しかし, 公教会機構の男性聖職者たちは, 892年 8 月29日, 教会の南側通路 の女子修道院用共同墓地にテオドラを埋葬させた。聖者伝では, 主人公のために聖なる 空間を創り上げるのに 3 つの手続きを踏んでいる。最初に, 修道女たちの墓を照らして いた油が聖油に特徵的な兆候をみせたとし，ついで，一度もこの女性聖者を見たことが ない画家が驚くほど見事な似像を描いたとする。それは適切な場所に掲げられ，このイ コンからも聖油 myron が流れ出した。しかし, 聖なる空間は, かく示されてはいても, 依然として彼女自身のものではない。第 3 のステップ, 聖遺物の移葬の話に進むのであ る。聖者は, 夢の中で修道女たちを呼び, 自身が本来の墓に移されることを告げる。し

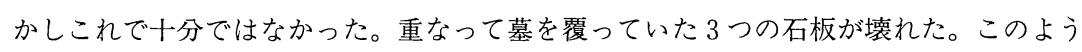
な中で，テオフィスタは浮彫を施した石棺を一つ作らせていた。それは聖油が外に流れ 出るための穴を備え, 頭の位置で開口部をとってそこを板で塞ぐという仕様だった。893 年 8 月 3 日, テオドラがそこに移される準備が整い, こうして固有の空間をもったので ある。イコンとランプが石棺の上に置かれことは間違いないと思われるが，聖者伝には 何一つ記されていない。他方, 聖油はしばしば穴から流れ出て, 教会の大地いっぱいに 広がったという。こうして聖なる空間と奇跡が教会のあらゆる場所に広がった。

テオドラは，存命中に固有の聖空間をもつことはなかった。事態は没後埋葬されるま で続いた。埋葬時点で, ステファナ修道院を担当する教会聖職者たちが, 彼女の聖性を 否定していたのは明らかである。つまり，この時点で聖者伝作者は必要とされてなかっ た。しかし, 彼女が奇跡をなし, いくつかの幻影を見せてからは, 聖性を得るのが必要 と考えられるようになった。この時点で, 聖者伝作者は聖遺物の移葬に関する説明を記 している。それは，伝記執筆のまさに直前だったと思われる。こうしてテオドラは真の 聖者になり，独自の聖空間を手に入れた。

聖者伝作者の目を通して見られる聖空間。柱頭聖者は，この点で特に興味深いカテゴ 
リーを構成する。現象は，459年没の大シメオンから，11世紀末のゲラシオン山のラザロ スまで, 追跡することができる。大シメオンと, それと対を成す 6 世紀の小シメオン $(592$ 没）の場合, 聖者伝テクストと考古学上の聖所の遺跡を照合させることも可能だ。垂直 面に向かう柱頭の存在そのものが，他のパターン以上に空間問題を提起する。

配置パターンに関する諸定義はすべて大シメオンに遡る。大シメオンについては, 上 述の聖者伝のほか，考古学の発掘報告を手にすることができる。聖者伝記事はいずれも， 柱頭が存在しない段階, つまり創設時の出来事では一致する。つまり, 乾いた石の壁で マンドラを築いていた，という点である。空間内は，シメオンが多数の訪問者から逃れ るために建てた柱以外に何もない。群衆から逃げるために場所を移ろうとしなかった彼 は，高みに逃れた。とにかく高い場所に，3，4，5本と柱が連立して建てられ，ある ものはとうとう18メートルほどにもなった。テクスト諸版を読み比べると，それが洗練 された空間構成だったことが理解される。マンドラの外に目を転ずると，女性の侵入は 断固禁止されていた。ギリシャ語版テクストは, シメオンの母親の悲痛なエピソードを 伝えている。彼女は，20年間姿を消していた息子とついに再会し，梯子を用いて壁によ じ登ろうとした。しかし聖者は立ち入りを拒否し，母親はマンドラの入口手前で座った まま息絶えた。伝記は，聖なる空間としてのマンドラ内部と，そうでなかった外部とを 明瞭に対立させる。女性の立ち入りは禁じられ，不信心者や悔悛者もまた遠ざけられた。

人々は，マンドラの入口を横切り，柱の他には何もない聖空間に入った。聖者に嘆願 をし，その説教に耳を傾ける訪問者が出入りしたのもこの入口である。この空間には柱 のみが惩え立っていた。柱の頂きには屋根のない囲いがあって, 備えられた梯子で登る ことができた。梯子を登り，聖者が開け閉めをする囲いの空を通して聖者と対話が許さ れるのは，最高の栄誉だった。なお，この囲いの周囲には何の台もなかったようだ。

ギリシャ語版伝記には, 聖者の没後に起こったと考えられる別の困難を見ることがで きる。伝記は「群衆は，彼（シメオン）に，石製の乾いた二つのマンドラを建てさせた。 そして, 内部のマンドラへの門を置いた」と語るのである。これは, 外側のマンドラに は門がなかったことを示唆する。第 2 のマンドラはその後見ることができない。聖者の 母親に関するエピソードで言及される4つの扉と同じであるかもしれない。

シメオンの周囲の空間編成には第 3 のステップがある。群衆が, 実際のところ実に頻 繁に聖者のそばにやって来たので，マンドラの大きさが十分でなかったのである。ギリ シャ語版伝記においては, 聖者の死後, 柱が立っていたコリュファエス山の全体が, 信 者で溋れかえったという。群衆が集まる山一ここれは聖者の空間の,より大きな区域だっ た—とともに，空には鳥たちの鳴き声がこだまするのが聞こえた。それは，ちょうど マンドラ周辺の空域,つまりは聖者のより狭い聖空間の周辺だった。このまさに真ん中 
に，聖者が暮らし，休む柱が覕え立っていた。

我々は，考古学のおかげで，聖者の死後数年の間に複雑で高度にヒエラルヒー化され た空間を立証することができる。直ちに前提となる事実を指摘しておこう。すなわち， 第 1 の聖遺物つまりシメオンの身体はアンティオキアへ運ばれたが，柱は残ったという こと。これは, 他の何よりも聖遺物の代わりとして機能した。なぜなら，信者とともに 在るという事実が大きな意味をもったからである。柱は，完全に聖者と同一視された。

聖なる空間の編成は，山の子もと，テサロニソスと呼ばれる村から始まる。巡礼者は, おそらくそこでアーチに出会った。村の縁にあるそこから，聖なる道は始まっていた。 道は，三重の扉を通って最初の空間入口へと繫がる。この平坦な空間は，貯水槽を除い て特別の整備があったとは思われないが，隣接する空間へと繫がる壁に囲まれていた。 その場所は, すでにマンドラの内側であった。この第 1 の囲いは，宿泊施設と，それに 近接する洗礼施設とによって, 第 2 の囲いから区切られている。宿泊施設に沿って, 4 対の門に従って行くと, 我々は, 完全に閉ざされ四隅が仕切られた第 2 の空間に入る。 前の空間と同様に, この空間も，柱のある山の頂上へと向かう傾斜の内にある。その北 側では, 十字架型の殉教者像 marthryon が南面を向けて匴え立っている。3 つの門へと 通ずる威厳あるポーチがそれに続く。女性たちはシメオンの禁止を遵守し, 教会の中へ は入らず，周囲の建物の方へ散っていった。

こうして人々は聖遺物一柱一に辿り着く。その柱に向けてバシリカ式アームが集まっ ているのが見えるだろう。柱は，6世紀半ばに崩壊以来再建されなかったピラミッド状 の屋根をもったオクタゴンの中心に位置している。聖者が存命中は, これが巡礼の本来 の目的地であった。聖者の死後, 巡礼は, バシリカの東側で行われたミサで終わった。 ここは，聖遺物がそこに存在しないことから，特異な聖所だった。

柱頭行者小シメオンについては，考古学と聖者伝テクストを比較することができる。 なぜなら, 柱の存在する聖所が, 聖者の存命中に建てられたからである。崇高な山 Mont Admirable の頂上に滞在の当初, 聖者は, 修道士の共同体に囲まれながら, 山の頂上に ある岩峰に座った。この峰から，聖者（もしくは，母親も含む聖者を取り囲む人々）は， 今日なお見られる施設の全体を建設すべく，近くの山を掘らせたのだった。これには， 551年 6 月 4 日に聖者がその上に登ることになる柱の土台も含まれていた。以後, この建 物群はよりコンパクトになる。地形の影響もあって全体が高度に集中化され, 聖所の囲 いも，テラニソスにあるものよりはるかに小さな区画しか占めなかった。

大シメオンとテラニソスの聖所, そして 1 世紀後の小シメオン。両者を比べると, 多 くの類似点があるものの, 大小の変化もまた確認される。1世紀後, マンドラはなお大 きな役割を果たしていたが，修道院の囲いの壁として機能していた。扉の開閉の有無は, 
聖者が柱に登る際に大変重要だった。女性はもはや排除されない。これには，おそらく 小シメオンの母マルタが大きな影響を及ぼしている。さらに重要な変化は, 聖者が, 存 命中から修道生活と典礼構成の中に統合されていることだ。柱頭行者のマンドラは, 最 初から修道院の囲いと一致しているのだ。小シメオンは先行者を真似ようとした。にも かかわらず, 彼は, 聖者が修道院制度という日常的枠組みの中により緊密に統合される 方向で大きな変化をもたらした。ビザンツ社会における聖なる空間の定義に，大きな変 化をもたらしたのである。

2 人のシメオンの直接比較は確かに有用ではある。しかしここで, 両者を結ぶ展開過 程の中に，もう一人の主要な柱頭行者夕゙ニエルを入れてみよう。大シメオンと同様，ダ ニエルもすでに長いこと修道生活を送っていた。当初は東方地域で, のちにコンスタン ティノープル近傍においてであった。首都近傍に移ったとき, 彼は51歳で柱頭行者になっ た。都から（かくして皇帝や総主教のもとから）15km ほどにあったダニエルの柱の位置 取りは，必然的に種々の出来事の展開や空間編成のあり方に大きな影響を及ぼした。

ダニエルの場合も，シメオン同様，柱頭行者としての物語はマンドラと柱の建設から 始まった。しかし，訪問者の殺到と皇帝の圧力という 2 つ外的強制により，状況は急 速に変化していた。ダニエルのもとに訪問者が殺到していたことを前提に，皇帝レオン 1 世（在位457-474）は，避難所なして訪問者たちを放っておくことはできない，とダニ エルを説得しようとした。訪問者の中には，奇跡を得るまでそこに留まる者もいたから だった。ダニエルは, シメオンが生涯に渡ってマンドラの中に生ける者の住処を設けて いない, と主張して，当初これを拒絶した。しかし，皇帝は変更を迫るあるものをもっ ていた。すなわち, シメオンの聖遺物である。結局ダニエルは，1つには聖遺物を受け 入れるため, マンドラの中に廟 martyrion を建設することに同意した。さらに，マンド ラの壁にまたがるかたちで，宿泊施設を付置する修道院の建設にも同意した。修道生活 は，こうして柱頭行者の空間に闖入したのである。もっとも，マンドラはダニエルの聖 空間のままであり，いずれの重要な出来事もそこで起こったのだった。

マンドラ中の空間に位階が設定された。柱すぐ脇の区画，柱そのもの，さらに最高位 に，それより一段高くなった台座があり，特に神聖とされた。事態は，ダニエルに強制 された叙階式のエピソードが物語っている。レオン 1 世は, 総主教ゲナディオス（在位 458-471）に，聖者に司祭の位階を授けることを強く望んだ。しかし聖者はかかる栄誉を 拒む。ダニエルが, 階段が架けられるのを拒んだので, ゲナディオスはそこから距離を おいて叙階式を執り行った。結局名ニルは，階段をつけさせたままにしたので，ゲナ ディオスは登ってきて，主教と新司祭が相互に聖体拝領をし合うことになった。周縁部 で授けられた最初の秘蹟があったからこそ, 第 2 の秘蹟が, 至聖なる区域, つまり台座 
で, 主教と聖者との直接交渉によって執り行われることになった。空間のヒエラルヒー がより一層示されたのは, 聖者の死に際してだったろう。数え切れない人々がマンドラ に集まり, 聖者の死を見守るなか, 総主教エウフェミオス（在位490-496）は, ダニエル がまだ存命であることを確認するために柱へ登った。聖者の死後, それは493年12月12日 の明け方であったが, エウフェミオスは再び柱へ登り, 遺骸を抱きしめた。そして, 聖 体を下ろす特権をもった高位高官たちが彼に付き従った。このなか, 他の位階の低い人々 は, 下で待機していた。聖なる空間のヒエラルヒーは, 社会的ヒエラルヒー, 教会的ヒ エラルヒーとあからさまに符合していた。

ダニエルの葬儀の後, 遺体は修道院内に埋葬された。その際, マンドラの空間は次の ように分けられた。つまり, マンドラの外, 遠くからも眺められる柱, 聖シメオン聖廟, その聖廟の礼帱堂内にあるダニエルの聖遺物, である。この区分は, 大シメオン死後の テラニソスのマンドラよりもはるかに多かったが, 数年後にコリュフェウス山に展開さ れる建物群の数よりはるかに少なかった。いずれにせよダニエルの生涯は, 柱頭行者の 空間が，修道院空間の通常の配置に倣う第一歩になったことを示している。

ここで, ルカス (979年12月11日没) に言及しておこう。ルカスの柱頭行者としての実 績は935年に始まる(その時彼はすでに56歳になっていた)。ルカスは, カルケドンのエウ トロピオス修道院内にあった柱を再利用したので, 聖なるものに転化すべき空間をもた なかった。ここでは, 柱頭行者の聖空間の中に修道院が建てられるのではなく, 柱が修 道院の空間に含まれていた。『ルカス伝』(BHG 2239) は, 聖者の周囲の聖なる空間に関 心を示さない。当地の教会権力との衝突もない。柱を再利用するに当たってルカスはカ ルケドン府主教に控えめに要求をするが, すぐに祝福を受けた。彼は, 死後コンスタン ティノープル市内のバッシアノス修道院に埋葬され, 彼はこの修道院の再建者と呼ばれ た。彼の遺骸は彼にとって借りものの聖空間を離れ, 彼がそこに手を入れ, 改変するこ とはなかった。さらに付言すれば, ルカスは, 教会機構のなかに位階を得ていたばかり か, 世俗社会にも少なからず組み込まれていた。ルカスの柱は, 同じエウトロピオスと いう名の港から数メートル離れた，町なかの修道院の内にあった。そして，その修道院 には漁場が付属しており，漁師たちは彼に十分の一税を支払っていたのである。これは 新しい現象ではなかった。9世紀，レスボス島のシメオンもまた，町の港の内側にあっ たテオトコス・ピオス修道院の中に柱を建てていた。

この柱頭行者現象はビザンツ社会で標準的なものとなっていった。しかし，それは一 直線に展開したわけではなかった。ガレシオン山のラザロスは, 柱頭行者という存在が, 少なくともある部分においてなお規範から外れた存在だったことを示している。ルカス とは対照的に，ラザロスはエフェソス府主教に対し一貫して反抗した。教会機構の意向 
に反して次々と柱を建てたため, 在籍していた修道院から逃亡していたのである。府主 教は, ラザロスが柱の周りに建てた修道院と一一ガレシオン山中のますます奥深くに なっていった——，それに帰属する不動産に，再び害効的な権威を及ぼそうとしていた。

967年生れ，1054年没のラザロスは，山と孤独について再考させてくれる存在である。 ラザロスはまず，既存のサンタ・マリアの庵（エルミタージュ）で柱頭行者としての才 能を 7 年間鍛え上げた。これには，庵の修道院への転用を認めるエフェソス府主教から の祝福が付いていた。ところが, この修道院はエフェソスに通じる街道近くに位置して いた。このためラザロスは, サンタ・マリアの庵を見下ろすガレシオス山の方へ引込む ことを決めた。ガレシオス山は，聖者の聖なる空間を全体として構成することとなった。 つまり,そこに入るためには, 岩に掘られた十字架のある場所から, 狭险路を通って行 かねばならなかった。そこは, ラザロスが悪魔を退治するのに十字の徵を使いたまさに その場所だった。いったんこの恐るべき場所を通り過ぎると, 人は, 魔除けの聖者の保 護を享受する。ラザロスは，狭險な地形のこの純化された場所に一連の柱を建てた。

ラザロスは，ガレシオス山上に連続した 3 本の柱を建てた。そして 3 つの修道院，つ まり救世主キリスト修道院, テオトコス修道院, 復活修道院, をおよそ 12 年間隔で建設 した。ラザロスは，崇敬の山で当時繁栄を見ていた小シメオンの修道院を訪ねていたが， その彼とともに山への関心は戻ってきたのである。ラザロスの施設群は狭险地に位置し ていた。しかし，彼は明らかに伝統を保持していた。柱の建設に続いて修道院を建設す る。柱頭行者も修道院なしではいられないのである。

伝統が保持されたとはいえ，様々な変化の方がはるかに重要である。マンドラという ことばがもはや使われず, 囲いも存在しない。修道士たちは, 鍵付き扉のある壁の建設 を要求したが, 無駄だったという。聖者の死後のこととして, 修道院から締め出された 修道士が院の門のところで 7 日間居座ったというエピソードが残されている。これは, 明らかに共同体が急いで囲いを処置したことを示している。さらに，修道院は長らく女 人禁制だったが，ラザロスの修道院へは女性が驚くほど自由に出入りしている。そのう ちの 1 人は，聖なる赦免を手にするため敢えて柱に登りさえした。

柱ということば自体もまた意味内容を変えていうた。柱という語は，もはや漠然と柱 を意味するのではない。それは，柱の中でも最も聖なる場所を指すようになった。つま り，柱の頂上う，聖者の囲い，を指し示す。その囲いは，周囲が閉ざされてはいるが，

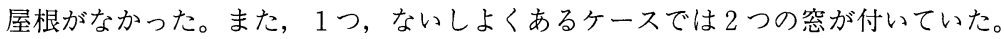

新しいケースの各々で柱が最初に登場する。しかし, 聖者伝作者たちは, 修道院内で 日常見られる建築物についても, 総じて直ちに付け加えた。庵 kellia, 聖堂, 調理場, 食 堂, 宿泊施設。これらの全体が, 厳密な秩序がないまま中庭に配置されている。聖堂は, 
柱とほぼ同等に重要である。そして, 聖者伝作者の書き方を見ると, 柱が聖堂の内部に あったか, もしくは聖堂のすぐそばにあったと考えたくなる。例えば, 修道士ゲオルギ オスは, 修道院の食料品保管係兼伝記作者だったが, 彼は, 他の修道士たちが聖堂内で 詩篇を朗誦している間に, ナルテックスで居眠りをしてしまった。彼は, 髭面の男が彼 の方へ向かってくる前に「柱が立つ聖歌隊席の場所に向かっていく」幻を見た。聖者は， 柱の上の囲いの空を通じて, 教会内部で起こっていることを知ることができ, 朗唱や典 礼と搫がっていた。彼が修行の最中にうとうとすると, 周囲の人間は竿で叨いて彼を目 覚めさせた。要するに, 柱は聖堂内部に置かれたか一一聖者が屋根のない囲いの中に居 たわけだから，それは驚くべき特徴であるが—，もしくはアプシス近くに，いずれに せよその煉瓦の内側に設置されていた。レスボス島のシメオンは，テオトコス教会の中 で起こっていることを見ることができた。彼の柱は教会聖堂近くに立てられていた。逆 に，ラザロスの囲いに登るのに使われた梯子は，教会の外に置かれていた。それは，ア プシスに近い場所であったことを確認する事実である。柱は, ルカスの柱に見られるよ うに, 修道院のある種の付属物ではない。また修道院は, 初期の柱頭行者に見られるよ うに，柱の付属物ではなかった。柱は，以後，完全に修道院の空間に組み込まれてゆく。 別の観点から見ると，ラザロスは修道院制度の展開に完全に一致している。第一に， 彼は様々な施設を一うのシスう公に統合し，最後に規則を起草した。彼は，設立者たち によって作られた大きな流れの中で独自の役割を果たし，より厳格な組織へと向かうビ ザンツ修道制度の展開に寄与している。第二に, 彼は, 自身の保有する諸修道院一一彼 が特別な地位を与えたものでなく, 教会の位階制に依った諸施設一と, 皇帝より設立 されたべサイ修道院—よって帝立修道院のステータスを有する一一と差異に基づく 不動産システ㕕組織化した。ラザロスは, 異なる修道院の所領から得られる収入に多 大な配慮をしていた。つまり, 修道院の複合施設群の中にとけ込む傾向にある柱を別に すると, 11世紀ビザンツのその他の修道院と, ラザロスの修道院との大きな違いは存在 しなかったのである。

聖者伝作者が紹介する聖空間は，こうして，主人公が実践する苦行のタイプによる。 䧮修士，そう表現するのはおそらく不的確で, 放浪修道士 gyrovague と言うべきだが, 例えば，常に不安定な生活に苦しんでいた小エウテュミオスのような者は，空間問題に 心配を向けない。共住修道士は，定義からして囲まれた空間で生活しているわけだが, 少なくとも男性であるなら外出することはあった。柱頭行者は，隠遁生活をしているこ とが明らかだから，一見すると鿵者と考えられよう。しかし，実は逆に，聖者がいった ん柱頭上に収まってしまうと, 独自の空間内での全く安定した生活によって特徵付けら 
れる。

伝記は常に聖者の死後に書かれる。したがって，彼はこの件については口出しができ ない。聖者伝作者の伝える内容は, 時間の経過の中で発展し, 聖者の生前, 没後に起こつ た事柄を語るに応じて変化する。彼の観点は, 聖者の生きた時代に反映される。おそら く, 聖なる空間の編成は, 聖者その人ようも, 聖者伝作者の心配事だうた。殉教者の時 代が遠のくにうれ，聖性は，聖者が生きていたときほぞは認められなくなうた。それは， おうらく教会機構が聖化の手続きに関してますます強力な権限を手にしていうたからで ある。聖者の存命中に聖化の手続きを執ることはより難しくなり，それゆえ聖者伝作者 の仕事もより困難になっていった。

空間を聖なるものにするのは聖者である。彼が聖的であればあるほど，彼が暮らし， 行動した場所も，神聖なものになる。彼は，死後になってはじめて聖者になる。まさに そのとき初めて, 彼の空間は神聖化される。この点で, 柱頭行者が連続したのはとりわ け重要である。大シメオンは，マンドラの中に修道生活空間をもたなかった。しかし， かくも狭い空間を彼自身で聖なるものとした。6世紀の後，貯蔵係グレゴリオスは，当 惑したままラザロスが柱の上でうとうととしたことを我々に伝えてくれた。柱はまさに 教会に組み込まれていたのであり，教会に比べて二義的になっていた。かくして，普通 の修道士が彼を竿で吒き起こすようになっていたのである。我々は，こうして空間の聖 化という主題が，どのように変化していったかを計測することができる。聖性という全 体現象と同じく，空間の聖化という問題もまた，ますます拘束的になうていうた教会シ 文云の中に次第に統合されていうたのである。

\section{【解 説】}

ミッシェル・カプランMichel Lucien Gaston Kaplan 氏は，1946年 4 月生まれ。ソル ボンヌの学統を受継ぎ，国際的に活躍するビザンティニスト，中世学者である。パリ第 一大学附属のビザンティンおよび中世中東の歴史と文明研究センター教授として長らく 同センター長を兼務した後，1999年よりは同大学学長を務めている。

以上にご紹介したのは，2003年 5 月10日 (土）に一橋大学で開催されたセミナーでの講 演原稿である（本訳稿はフランス語原稿に依ったが，当日は氏の御好意により英語原稿 での講演となった)。同セミナーは，多忙な来日スケジュールの中，わが国の同僚諸氏と の交流を楽しみにされた氏の御厚意によって実現し, 日本ビザンツ学会と一橋大学地中 海研究会によって共催された。幸い国内からも同学者が多数参集し, わが国斯学界にとっ ても意義ある集会となった。

当日は，標題の通り，斬新な視角からビザンツ社会を捉える問題提起的な話題が提供 
された。写真・図版映写を交えた氏の解説は，ビザンツ学の新たな展開の一つを示して 興奮を誘った。それは，氏の学問蓄積に裏打ちされて，奥行きと幅のある刺激的な問題 提起となった。

本訳稿に添えて，ここでごく簡単に氏の学問的足跡をご紹介しておきたい。それは, 本テーマに至った氏の問題視角を浮き彫りにする上でも無益ではないと思われる。

氏は，まさに戦後ビザンツ学が白熱した学問論争を展開する時代にビザンツ学の道に 入った。1950年代から60年代にかけて，ビザンツ学もまた社会経済史研究重視の傾向に あった。その主柱には，中世社会論の中核としての「封建制論」があり，ソルボンヌの ビザンッ学もその論争の㘧外にはなかった。フランス学界を代表したポール・ルメルは, 当時隆盛を見ていたマルクス主義史学に対するアンチテーゼを提示して注目を集めてい た。1961年の国際ビザンツ学会第16回大会 (於オフリド)でのメインテーブルは「封建制」 論を基調とする「都市と農村」論だったが（ピグレフスカヤ他著，渡辺金一訳『ビザン ツ帝国の都市と農村』創文社歴史学叢書), このとき, 司会を担当したルメルは, マルク ス主義研究者の問題構成に対する自身の異論を，「財政至上主義」fiscalité,「国家統制主 義」 étatisation として提示していた（渡辺「ビザンツ封建制の諸問題——論争の展望」

『社会経済史学』30-3/4 (1965) p. 73-109.を参照)。

ルメルのもとに集ったビザンティニストたちは, この学問状況の中で各自の作業課題 を彫琢, 推進していった。アテネ大学に戻るまで社会科学高等研究院 EHESS に滞在し たニコラス・スヴォロノスは，13世紀の『テーべの土地台帳』を精細に分析して自由農 民共同体の姿をヴィヴィドに描き出したし，ソルボンヌの講座をルメルより引き継いだ エレーヌ・アルヴェレールは, スミルナ近傍レムビオティッサ修道院の文書等をベース に緻密な地域分析を積み重ねながら，国家制約のもとにあったビザンツ的「条件的土地 保有」の類型化などを試みた。他方, ルメルの指導で推進されたアトス山修道院文書の 校訂作業は，今日までジャック・ルフォールに引き継がれて国際学界の注目を集めてい る。

ルメルらの研究は, 封建制論者たちの概念先行型推論とは異なり, 精緻な史料研究と それに基づく地道な地域研究を信条としていた。そして, 作業の進展とともに明らかと なる国家現象の遍在性は，ますますもって彼らの問題構成の中核を構成していった。ア ルヴェレールの後継者として講座を担当したカプラン氏の学問生活もまた, 主題と方法 の点でこの学統に連なっている。

氏の関心は, 後期ローマ帝国の諸法令を系統的に分析して帝国＝教会関係を制度論的 に定位した最初の著作 Les propriétés de la Couronne et de l'Eglise dans l'Empire byzantin (Ve-VIe siècles). Paris, 1976. 以来, 国家と教会の関係に収斂していた。聖と俗 
の関係を問う視点は, 教会・修道院所領を検討素材としながら聖俗貴族論一般を展開し た封建制論争の，論理上の欠陥と無関係ではない。ビザンツ国家と教会の関係は，封建 制的なそれではない。この基本認識に立って, カプラン氏は, 帝権と教会・修道院制度 の財政的，経済的関係を復元しようとした。この視点は，学位論文を基礎とした主著 Les hommes et la terre à Byzance du VIe au XIe siècle. Paris, 1992. で十全な展開を見せるこ とになる。この中で氏は, 聖者伝資料を多用する。国家財政文書や教会・修道院所領文 書など，伝統的な史料素材を基本としながら，新たな素材から得た知見をも豊富に盛り 込んで，土地制度，社会関係分析を全面的に記述しようとしたのである。

八ギオグラフィが提供するのは, 法令等の規範史料からは期待できないビザンツ社会 の現場情報である。帝国権力が，多少ともキリスト教の聖性を帯びて立ち現れななら， その依って立つ足場を丹念に確認する必要がある。また, 聖人崇敬が帝国社会の中で大 きな比重を占めたなら, 神の代理人たる皇帝と「聖人」との関係についても見通しを得 ておきたい。氏の分析対象は, 帝国財政と皇帝など俗人の支援を受けて存立した教会施 設・財産の基盤形成分析から，俗権と聖性の関係を社会の現場でリアルに把握する方向 へと展開していった。

ただ，聖者伝史料を虚心坦懐に読むことで，ビザンツ社会の聖性理解が得られるとい うものでもない。その後のカプラン氏の作業を規定したのは，このく聖性の存立構造> だった。本稿でも，テキストと考古学上の知見を総合して「聖性」の存立態様を事例に 即して定位しょうとする。しかしそれは，何よりも聖者伝作者における執筆の意図と目 標を，「聖性」をキー概念として探る試みとならざるをえない。テキストは，現実に在っ た事柄を客観的に記述した痕跡というより，何よりも執筆者の意図と世界観の表明であ る可能性が高いからである。現実世界もまたテキストの力を通じて実現する。テキスト と現実世界との関係を巡るこの想定は，いわゆる言語論的展開以降の歴史学と微妙に呼 応してもいる。テキスト上の「事実」 facts としての「記述」descriptions と，テキスト の背後に存する「現害」 reality，さらにはまた歴史を創り上げる「真実」truth としての 社会の磁場（デュナミズム）をめぐるスリリングな解読。本講演は，この先端的作業の 現場を平明に紹介する貴重な機会となった。この研究動向は, ビザンツ学の分野でも， カプラン氏等を先導者として今後さらに深化していくにちがいない。 